\title{
THE MAKINGS OF A GOOD LAW SCHOOL?
}

\author{
MICHAEL TREBILCOCK*
}

\section{MY PERSONAL ACADEMIC ODYSSEY}

Over the course of an academic career spanning about 27 years, I have seen inside many different law schools. I undertook my initial legal training at the University of Canterbury Law School in Christchurch, New Zealand, between 1959 and 1962. I entered law school out of a country high school. In my first year, there was only one full-time academic member of staff, the balance of the instruction being undertaken mostly by young or struggling practitioners who required extra income. By the end of my degree, the school had inched up to three full-time academic staff. Moreover, many of the students were part-time, with students after their first or second year simultaneously clerking with local law firms. On moving to the University of Adelaide Law School in 1963, as a tutor while simultaneously undertaking an LL M by thesis, I encountered a law school which initially had six or seven full-time members of staff, with a great deal of practitioner instruction and much part-time study by students. By the end of my time at Adelaide in 1969, the Faculty had increased to perhaps 12 or 14 full-time staff members. On moving to the McGill Law School in Montreal in 1969, I encountered my first full-blown law school, with perhaps 25 full-time members of faculty and a fulltime student body and national programmes offering degrees in both common and civil law, as well as a significant full-time graduate programme. On moving to the University of Toronto Law School in 1972, I joined what was perhaps regarded as the pre- 
eminent academic law school in Canada, with strong and proud traditions of innovation in legal education, although at that time afflicted with a degree of parochialism and complacency that was at variance with these traditions. During the ensuing 18 years at the University of Toronto, I took a leave at the University of Chicago law school in 1976 and was exposed for the first time to a law school with a strong commitment to interdisciplinary studies, especially, in my case, law and economics. A further leave at the Yale Law School in 1985 exposed me to an even broader range of theoretical and interdisciplinary perspectives on law. Both Chicago and Yale also have strong traditions of organised collegial forums for review of research work in progress. In the course of the last year, I have been associated with two law school reviews on a pending change of command: first, our own Law School and secondly the University of British Columbia Law School. And most recently, I have spent four weeks at the University of Melbourne Law School, revisited my first academic home, the University of Adelaide Law School and made brief visits to Monash and the University of Sydney law schools.

\section{Law and Learning (the Arthurs Report 1983)}

A study of Canadian legal education undertaken by a task force chaired by former Dean Harry Arthurs of the Osgoode Hall Law School recently provided a relatively unflattering evaluation of Canadian legal education. The chairman subsequently summarised his views as follows:

Canadian legal scholarship ... is too monolithically committed to traditional analytical methods, too preoccupied with an agenda of issues defined by professional priorities, too deeply immersed in formal legal documentation, and too firmly implicated in the value structures and mind-set of the practising bar and government law reform activities. ${ }^{2}$

In a survey of Canadian law professors undertaken by the task force, 40 per cent of the respondents indicated that they were planning to leave teaching. Forty per cent of the respondents also indicated that they devoted 10 per cent or less of their time to selfinitiated research, only about 20 per cent devoted more than one quarter of their time to such research. Of research undertaken, more than 80 per cent was found to be of an expository or doctrinal nature and not to reflect any serious theoretical, interdisciplinary, or 
empirical dimensions. Only miniscule percentages of the respondents indicated any primary interest in areas such as legal history and jurisprudence. Between 20 and 25 per cent of the teaching load on average in Canadian law schools was undertaken by part-time teachers, typically practitioners.

\section{THE UNIVERSITY OF TORONTO LAW SCHOOL’S MISSION}

Over the last 15 years, in an attempt to shed, or distance itself from, this general profile of Canadian law schools the University of Toronto has pursued something of a transformatory mission. In the Law School's complement plan, approved by the central administration of the University in 1987, we declared that our objectives were as follows:

The goal of the Faulty of Law is to be the pre-eminent centre for research and teaching in law in Canada, and one of the great law schools in the common law world. With respect to research, our goal is to undertake theoretical, doctrinal and interdisciplinary scholarship of national and international significance. With respect to teaching, our goal is to provide an outstanding and rigorous liberal education in law to undergraduate students of the highest promise, and a researchintensive, thesis-based programme of high distinction for graduate students at the masters and doctoral levels. The Faculty seeks also to maintain a central place within the University as a whole academically through rich interdisciplinary linkages, and administratively through service to the University community at all levels.

The development strategies pursued by the Law School over the past 15 years under the successive Deanships of Professors Martin Friedland, Frank Iacobucci and Robert Prichard might be summarised as follows:

\section{Student Body}

The LL B student body comprises about 500 students, almost all with pre-law degrees. On average an A grade in one's pre-law degree is required to gain admission. About 2500 students compete for 175 first year places. About 30 per cent of the students come from outside the province; two-thirds of the balance hold pre-law degrees from outside Toronto. Indeed, about 85 different Universities are represented in the pre-law qualifications held by our students. Despite this intellectual and geographic diversity, 
which is crucial to our conception of ourselves as a national law school, the issue of diversity in the student body has emerged as a concern. Most of our students are drawn from higher socioeconomic strata. While the student body is almost in balance in terms of gender, very few visible minorities are represented in the body. A related concern is that too high a percentage of the student body, from too early a stage, see their natural career progression as taking them into the elite law firms in the country, and disregard alternative career paths. We are beginning to try to address some of these problems, by being more active in recruiting students from diverse socioeconomic and ethnic backgrounds and by mounting summer internship programmes in collaboration with Toronto law firms. Under these programmes students spend half their summers with the law firms and the other half either undertaking research with Faculty members or working with public interest or community groups, at the expense of the employing law firms.

With respect to the graduate student body, about five years ago we made a collective decision to increase the size of the body from 15 to about 30 and to increase available scholarships to attract a critical mass of first-class graduate students. About two thirds of the students undertake one year LL M degrees, primarily by thesis, with the other third undertaking two or three year doctoral programmes by thesis. More than half of the students are foreign; all graduate work is undertaken on a full-time basis. We have rejected the option of offering part-time course work LL M degrees to practitioners.

\section{Curriculum}

A general test that I would apply to the appropriateness of our curriculum is whether the majority of students graduate from our school with a broader perspective on law and life than when they entered. Given that almost all of them have pre-law degrees of one kind or another when they enter law school, this is not a trivial challenge.

With respect to the LL B curriculum, there has been an enormous proliferation of courses over the last decade and a half. Our Calendar now lists 140 course offerings over the three years of the LL B degree. Very few of these are compulsory. The first year programme comprising Torts, Contracts, Property, Criminal Law, 
Constitutional Law and Civil Procedure is prescribed, but after the first year students may take any courses they wish. Many of these course offerings may strike the reader as relatively exotic, for example, the Theory of Tort Law; the Theory of the Corporation; Social Science Evidence and Research in Legal Settings; Regulation - What Works and What Doesn't; Public Policy Formation; the Legal Philosophy of Hegel; the Limits of Freedom of Contract; Law, Gender, and Ideology; Law and Society; Law and Religion; Law and Liberalism I; Law and Liberalism II; Law and Modem Social Theory; Jurisprudence - Knowing, Reasoning and Judging; Jewish Law; Interpretation, Scepticism, Law; Ideas of Order, Images of Disorder and the Law; Gender Issues and the Law; Gender, Crime and Deviance; Feminist Theory: Challenges to Legal and Political Thought; Economics for Non-Economists; and Economic Analysis of Law. While we attempt, in our Calendar, to indicate to students natural groupings of subjects around potential concentrations of interest, only a small number of these courses are formally sequenced. The Arthurs Report was critical of what it referred to as a smorgasbord or cafeteria approach to legal education and if "riotous pluralism" is a weakness, we would feel compelled to plead guilty to it. However, some of the nonmainstream perspectives on law, in addition to being developed in upper-year seminars, are being increasingly integrated into mainstream courses. For example, feminist theory is integrated into family law and constitutional law courses, corrective justice into tort law and economics into corporate law, commercial law and international trade courses. The Arthurs alternative was to propose that law schools consider offering two parallel streams of instruction - one for aspiring practitioners and another for aspiring academics and public policy analysts - with the latter stream being tightly structured and sequenced to provide students with an exposure of increasing complexity to theoretical and policy problems. This proposal has not generally been sympathetically received in Canada. In my own case, I see it as an abandonment of the dream of providing all law students with a liberal, universitybased education (not a trade school education). ${ }^{3}$

Some four years ago, we introduced a major innovation in the first year programme. On four separate occasions during first year, for a week in each case, almost all the basic first year courses are 
suspended and all first year students are exposed to one week "bridge periods" in, for example, Legal History, Law and Economics, Legal Philosophy and Feminist Jurisprudence. These bridge periods ("Perspectives on Law") involve about 12 hours of instruction in large group lectures and smaller discussion groups and are evaluated by take-home exam at the end of the week. These exams are graded in the normal way and averaged over the four bridge periods to yield a grade for the bridges as a whole. I would hope that over time, the bridge programme will become selfliquidating, as we acquire the capacity to staff all our first year courses with faculty who represent a balanced range of perspectives on law. In the case of the upper year curriculum, we have introduced a mandatory extended research requirement beyond the normal essay writing requirements associated with upper year seminars. In addition, over the past four years, we have invited a series of distinguished visitors from US and English law schools to teach two or three week intensive courses for upper year students, typically involving about 15 contact hours and carrying half of a normal academic credit for a one term seminar. Visitors who have taught these courses over the past several years or who will be teaching such courses in the coming year include; Stewart Macaulay (Wisconsin), Owen Fiss (Yale), George Priest (Yale), Robert Clarke (Harvard), Joseph Raz (Oxford), Martha Minow (Harvard), Morton Horwitz (Harvard), Robert Gordon (Stanford), Cass Sunstein (Chicago), Carrie Menkel-Meadow (UCLA), Stanley Fish (Duke), Harold Koh (Yale), Jules Coleman (Yale), Karl Klare (North Eastern), Roberto Romano (Yale) and Robert Hudec (Minnesota). Future curriculum plans include an enrichment of our international human rights and international business and trade law offerings and an enrichment of our comparative and civil law offerings, both of which initiatives will give a more international outlook to the Faculty. Additional faculty hirings in these areas are contemplated.

With respect to the LL M curriculum, some five years ago we introduced a mandatory course for all graduate students in the first term of their first year at the law school, Alternative Approaches to Legal Scholarship. The course involves a series of two week modules canvassing perspectives on law such as legal history, law and economics, legal philosophy, law and sociology, feminist 
theory, critical legal studies and involving a number of members of faculty working in these various genres of scholarship, with one faculty member coordinating the course. Students are required to write five or six short critical review assignments on readings for weeks of their choosing and are evaluated on these assignments. Not only has this course served to broaden the research horizons of students and to introduce them early to a number of members of faculty, but it has had a very healthy effect on group dynamics by reinforcing a sense of group identity. The Graduate Law Students Association has become a very lively force in the faculty, having refurbished its own common room facilities and organising not only a range of social activities for graduate students, but two separate thesis retreats. One is held early in the year at the law school where doctoral students present an outline of their theses for criticism and five or six faculty members offer advice to the entering LL M students as to appropriate strategies for defining and tackling their research projects. The second thesis retreat is held out of town over a weekend early in second term where the LL M students each present an outline of their thesis for criticism by fellow graduate students and faculty supervisors.

\section{Faculty}

Our faculty consists of about 20 full professors, 7 associate professors and 13 assistant professors. Over the past six years, about 15 new faculty have been hired, most of them young assistant professors, a number with $\mathrm{PhDs}$ either in law or in cognate disciplines, and most with graduate training in US law schools. There is no dearth of first-class recruits available and we spend a great deal of time collectively on our hiring decisions which are reviewed by a large internal Hiring Committee of about 10 colleagues which solicits input from all members of Faculty. All our new recruits, in addition to whatever interests they may have in traditional or mainstream legal subjects, have substantial interests in interdisciplinary, theoretical or empirical scholarship. Over half of our faculty is cross-appointed to one or more of 14 cognate faculties, departments or research centres. Five economists, three political scientists, two sociologists and one philosopher are crossappointed from cognate disciplines to the law school and teach courses either alone or in conjunction with members of our faculty. 
Major theoretical groupings within our full-time faculty include: legal philosophy (6 colleagues), law and economics (5), feminist theory (5), legal history (5) and constitutional theory (7).

Our promotion procedures entail a three year probationary review by the Dean and a small committee of faculty, designed to provide a young colleague with some preliminary assessment whether he or she is on a solid trajectory, in terms of quality of teaching and research, towards tenure. The tenure decision is typically taken in the sixth year and involves a somewhat larger committee comprising a majority of faculty members, two representatives from cognate disciplines and external written assessments of the candidate's published scholarship. If the tenure decision is favourable, the candidate would at that point not only be tenured but also promoted to associate professor. The decision to promote to full professor is typically taken about six years from the tenure decision and involves a somewhat similar process to that entailed for tenure, except that the candidate would be expected to demonstrate at least a national and preferably an international reputation in his or her field. It should be noted that, in contrast to the Australian and New Zealand university systems, there are no artificially imposed quotas on the number of full professors and any young member of faculty who is talented and productive can normally aspire, in due course, to becoming a full professor. This encourages ambition, rather than envy or frustration, and also avoids the very demoralising institutional effects of talented people in mid-career moving off to other schools in pursuit of Chairs. Within the full professor classification at our school there are substantial salary differentials, reflecting annual decanal judgments of merit, based in part on detailed annual activity reports which each must submit. Scholarly productivity weighs heavily in decisions as to promotion, tenure and annual merit pay increases and all but about five members of our faculty publish serious scholarship on a regular basis. Mandatory student course evaluations are also administered in every course and the results reviewed in all major personnel decisions. Increasingly, a condition of membership on key Faculty Committees such as Hiring and Curriculum, is a strong scholarly record. Early retirement packages have been made available to older faculty members who have lost their zeal for scholarly pursuits. 
In order to encourage scholarly productivity, in addition to the university-wide sabbatical leave system (which typically entails one year off after six years of service), we have introduced an internal teaching relief system, where after three years of teaching a colleague may be relieved of teaching duties for a term to pursue a specified research agenda. Most members of faculty avail themselves of this privilege. In addition, in structuring individual teaching loads, as a rule of thumb colleagues are expected to devote about half of their teaching time to covering basic courses and the other half to teaching specialised upper year seminars which closely follow their own research interests and which are largely of their own choosing. We have also dramatically increased research funding from outside sources for research programmes and projects from a few thousand dollars to hundreds of thousands of dollars a year. A senior administrative officer is charged with identifying funding opportunities, alerting faculty to possibilities and deadlines and helping younger faculty prepare strong grant applications. In the case of young faculty members, we have cut teaching loads to about half the usual load (six hours a week) in their first two years of teaching.

A continuing concern to us, rather like that pertaining to the student body, is faculty diversity. While the faculty exhibits enormous intellectual diversity, the goal of gender balance is far from being realised and almost no visible minorities are represented on the faculty. About 10 of our faculty (25 per cent) are women a substantial improvement over the position a few years ago, but scarcely grounds for celebration. This is a delicate issue in the faculty, but has also been handled sensitively to date. We need, nevertheless, to continue to make significant further progress. The visible minority issue will be much harder to resolve, simply because the graduating pool of students is almost as unbalanced as the faculty. Between 30 and 40 senior practitioners are also involved in our teaching programme, almost all in upper year specialised seminars and almost none in core or mainstream courses.

With respect to outside work, our rule of thumb is that colleagues may spend up to one day each week on outside remunerated work, preferably of an academic character, such as work for a law reform commission or in government research. On- 
going formal liaisons with law firms are not encouraged and indeed do not exist. Academic salaries at present range from a starting salary of about $\$ 54000$ to a top salary of perhaps about $\$ 100000$. Unlike Australia and New Zealand, academic salaries are not on a national basis and are set within each university. Moreover, the law school at Toronto aggressively renegotiates its overall salary structure periodically with the central administration separately from the general university faculty. However, despite the much higher salary structure we enjoy relative to Australian legal academics, it must be remembered that Toronto is one of the highest cost housing markets in North America (which the University has failed to respond to with an effective housing assistance policy), and that in order to attract and retain talented staff, we are not only competing with much higher salaries in legal practice but also with significantly higher academic salaries at many top US law schools. Given these salary differentials, it is crucial to ensure that in all other respects the distinctive nonpecuniary returns to an academic career are as high as possible.

\section{Intellectual-Institutional Culture}

I believe that this is one of the most under-attended issues in a number of the schools that I have worked in or observed. Too often, collective collegial interactions surround administrative matters where we typically have little comparative advantage and much capacity for pettiness and incompetence. At the University of Toronto, we have increasingly attempted to develop collective collegial forums for the exchange of ideas and mutual criticism of each other's work in progress. In 1976, we established the Law and Economics Workshop which continues to meet on average once every two weeks throughout the year and where international guests present papers which have been circulated a week or 10 days ahead of time to regular workshop participants. A Legal Theory Workshop is also organised on the same basis and a somewhat more informal Women and the Law Workshop holds regular seminars. Further workshops are evolving in Law and Public Policy, Law and Society and Legal History. One of the dangers of which we need to be mindful with this proliferation of workshops is intellectual fragmentation rather than cross-fertilization. We are beginning to consider ways of ensuring significant overlaps 
between the activities of these workshops, for example, by scheduling a series of joint workshops. Preserving a precious ethic of tolerance and mutual respect despite increasing intellectual diversity, is a critically important institutional value. In other words, diversity should be viewed as a source of strength and mutual stimulation in a faculty, not a source of factionalism and paralysis, as it can so easily become. Perhaps surprisingly, given the scale of the changes, amongst major Canadian law schools our faculty is one of the least fractious and most collegial. This environment is also nurtured by regular faculty lunches (three or four a term where a colleague will discuss research in progress), and drinks in our faculty common room every Friday afternoon which a substantial number of faculty regularly attend.

\section{Facilities}

Some six years ago our physical facilities were the least adequate of any major law school in the country. However, we are nearing completion of a $\$ 14$ million library and classroom block reconstruction which will make our facilities amongst the best in the country. This will be complemented by a serious thrust to improve the quality of our library collection substantially so as to make it a major research library.

\section{Alumni - Legal Profession Relations}

Until a few years ago, our Alumni Association was largely dormant. As a public institution, it was generally assumed that public subventions were sufficient for our Law School's needs. Today, as a result of vigorous efforts by our Dean and administrative staff, the Association has been completely revitalised and has several thousand members and a number of chapters throughout Canada and beyond. The Association publishes a regular newsletter which is distributed to members and students, holds regular class reunions and regional chapter meetings, and an annual dinner where typically about 500 members attend and at which an annual distinguished Alumnus award is presented. Through the generosity of law firms and individuals, about \$5 million was contributed to the library reconstruction project. Prior to this massive fund raising effort, we had rarely received more 
than $\$ 15000$ or $\$ 20000$ a year from the Association. The Law Foundation, which disburses interest on lawyers' trust funds, also now gives the Faculty about $\$ 500000$ per year, which supports summer research assistantships and additional library acquisitions. The new International Business and Trade Law Programme in the Faculty also has enlisted about 20 law firms as founding members, each contributing \$5 000 per year to enhance the Programme's activities. I reject as unduly defeatist and apologist the view that we are helpless captives of narrow professional expectations or paradigms of the goals of legal education. ${ }^{4}$ It has been precisely at a time when we have dramatically broadened our vision of our academic mission that we have been able to enlist for the first time the serious support of the practising profession. The profession itself has been undergoing a major transformation, with many local and national law firm mergers and the establishment of presences in a number of foreign jurisdictions, which has eroded narrow parochial attitudes to legal practice and reinforced national and international perspectives on law. The profession is coming to accept that if they want a law school of international stature in their midst, they need to forge a partnership with us to supplement the financial contributions of the public sector.

However, as has sometimes happened at other law schools, persistently denigrating the importance of, for example, the corporate, commercial, trade and tax law areas of the curriculum, characterising practising lawyers as handmaidens of capitalist exploiters and parasites on the public weal and engaging in endless internecine warfare, is unlikely to commend an institution as warranting the support of the practising profession. Law schools should recognize an obligation to be strong in areas of direct relevance to the practising profession, whatever other strengths they possess or aspire to. The practising profession should in turn recognize the legitimacy of university law schools pursuing these other strengths and indeed, the importance even in areas of direct practical relevance to it, of a rigorous theoretical component in course instruction. This seems a reasonable and tenable trade.

\section{Faculty Autonomy}

My observations suggest that with respect to matters of curriculum reform, budgetary expenditures and personnel 
decisions, our Law School enjoys vastly greater autonomy than law schools in Australia or New Zealand. Obviously, our overall budget and total personnel complement are set by negotiations with the central administration, but most other decisions are made within the Faculty and subject to minimal central oversight. This provides much greater scope and incentive for innovation and adaptation than a hierarchical system of decision-making. Decision-making in our faculty is designed to facilitate, not constrain, the academic aspirations of talented and ambitious individuals. In this sense, our decision-making orientation is very much bottom up. Australia seems to combine a curious egalitarianism across institutions, where resources are spread evenly and thinly irrespective of relative institutional strengths, with a stifling hierarchy within the institutions, where career paths are arbitrarily truncated. The pursuit of institutional and individual excellence is inconsistent with both tendencies.

\section{CONCLUSION}

These, then, are the efforts that we have made at the University of Toronto to attempt to dig ourselves out of the mire so depressingly described by the Arthurs Report in its general review of Canadian legal education. Our aspirations are ostentatious, our achievements probably somewhat fragile and much remains to be attended to on a large unfinished agenda. We have also benefited from the inspired and consistent leadership of three Deans over 15 years during which a particular vision of the faculty increasingly took hold and was broadened and deepened. Many of these transformations were undertaken during the latter part of the 1970s and early 1980s when government funding to Canadian universities was declining in real terms. In order to offset these increasingly severe resource constraints, a new style of academic entrepreneurship in uncovering hidden resources became an indispensable ingredient in moving our institution forward.

In 1989, our graduate programme, and indirectly the entire Law School, was subject to an external appraisal by three reviewers from Harvard, Stanford and the University of Victoria). Their report reinforced our ambitions and nurtured further ambitions rather than any sense of complacency.

I am not at all sure that everything we have done at the 
University of Toronto is in some ultimate sense right, or even that some things which are right for us are necessarily right for other law schools or indeed could be readily transplanted to other law schools. However, I am convinced that any law school that is able to forge a substantial collegial consensus around a future vision of itself and with inspired leadership, has a host of small margins on which it can systematically move and which in aggregate provide enormous potential for change.

* Faculty of Law, University of Toronto. (C) 1990. (1990) 2 Legal Educ Rev 119.

1 Consultative Group on Research and Education in Law, Law and Learning: Report to the Social Services and Humanities Research Council of Canada (Ottawa: Social Sciences and Humanities Research Council, 1983).

2 HW Arthurs, To Know Ourselves: Exploring the Life of Canadian Legal Scholarship (1985) 23 Osgoode Hall LJ 403.

3 It was that dream which led to the "revolution" out of which the modern University of Toronto Law School was born in the late 1940s, after a bitter fight with the Law Society of Upper Canada which then ran a monopoly, proprietary law school. See CI Kyer \& JE Bickenbach, The Fiercest Debate (Toronto: The Osgoode Society, 1987).

4 See HJ Glasbeek \& RA Hasson, Some Reflections on Canadian Legal Education (1987) 50 Mod L Rev 777. 